\title{
Determination of Tetracycline in Pharmaceutical Preparation by Molecular and Atomic Absorption Spectrophotometry and High Performance Liquid Chromatography via Complex Formation with Au(III) and $\mathrm{Hg}(\mathrm{II})$ Ions in Solutions
}

\author{
Ahlam Jameel Abdulghani, ${ }^{1}$ Hadi Hassan Jasim, ${ }^{2}$ and Abbas Shebeeb Hassan ${ }^{2}$ \\ ${ }^{1}$ Department of Chemistry, College of Science, Baghdad University, Jaderiya, Baghdad, Iraq \\ ${ }^{2}$ Department of Chemistry, College of Science, Al-Mustansiriyah University, Baghdad, Iraq
}

Correspondence should be addressed to Ahlam Jameel Abdulghani; prophahlam@yahoo.com

Received 7 March 2013; Accepted 19 May 2013

Academic Editor: Peter A. Tanner

Copyright (C) 2013 Ahlam Jameel Abdulghani et al. This is an open access article distributed under the Creative Commons Attribution License, which permits unrestricted use, distribution, and reproduction in any medium, provided the original work is properly cited.

\begin{abstract}
UV-visible and atomic spectrophotometry and HPLC techniques were applied for the determination of tetracycline (TC) in pharmaceutical preparations via complexation of the drug with $\mathrm{Au}(\mathrm{III})$ and $\mathrm{Hg}$ (II) ions in solutions. The mole ratio of TC to metal ions was $1: 1$. Maximum peak absorption at $\lambda 425$ and $320 \mathrm{~nm}$ for the two ions, respectively, was optimized at heating temperature $75^{\circ} \mathrm{C}$ for 15 minutes at $\mathrm{pH}=4$ followed by the extraction with ethyl acetate. The percentage of extraction and stability constants for the two complexes was $95.247,95.335 \%$ and $2.518 \times 10^{4}, 1.162 \times 10^{5} \mathrm{M}^{-1}$, respectively. HPLC method was applied without extraction process. The analytical data obtained from direct calibration curves of UV-visible absorption, FAAS, and HPLC for $\mathrm{Au}(\mathrm{III})$ complexes were recovery $(100.78,104.85$, and $101.777 \%$, resp.); detection limits $(0.7403,0.0997$, and $2.647 \mu \mathrm{g} / \mathrm{ml}$, resp.); linearity $(5-70,5-30$, and $10-150 \mu \mathrm{g} / \mathrm{ml}$, resp.), and correlation coefficient $(0.9991,0.9967$, and 0.9986 , resp.). The analytical data obtained from direct calibration curves for $\mathrm{Hg}$ (II) complexes by UV-visible spectrophotometry and HPLC were recovery (100.95 and $102.000 \%$, resp.); detection limits $(0.5867$ and $2.532 \mu \mathrm{g} / \mathrm{ml}$, resp.); linearity (5-70 and 10-150 $\mu \mathrm{g} / \mathrm{ml}$, resp.); and correlation coefficients (0.9989 and 0.9997, resp.).
\end{abstract}

\section{Introduction}

Tetracyclines possess a wide range of antimicrobial activity against Gram-positive and Gram-negative bacteria. They have been used not only in human medicine for the treatment of infectious diseases but also as additives in animal feed to promote growth. Beside the pharmacological importance of tetracycline (TC), this molecule possesses many potential metal-binding sites. Therefore a wide range of research work has been reported on chelation of TCs with various metal ions which have been utilized successfully in pharmaceutical analysis [1-15].

Depending on the chosen experimental conditions such as solvent medium, $\mathrm{pH}$, metal ion type, and ligand: metal ratio, the $\mathrm{O}(10), \mathrm{O}(11)$, and $\mathrm{O}(12)$ on the $\mathrm{BCD}$-ring and $\mathrm{O}(1)$, $\mathrm{O}(3)$, and $\mathrm{N}(4)$ in ring $\mathrm{A}$ and at the carboxamide group on the A-ring are the main coordination sites that were frequently proposed in the literature $[1-6,16]$. Pharmacokinetics and bioavailability of TC are affected by its coordination with metal ions such as calcium in blood plasma and magnesium ion in the intracellular medium [4]. By combining with the copper, zinc, iron, and other trace metal elements in enzymes such as collagenase, tetracyclines inhibit the enzymatic destruction of tissues [5].

Complexes of (TC) with $\mathrm{Co}(\mathrm{Il}), \mathrm{Ni}(\mathrm{II})$, and $\mathrm{Fe}(\mathrm{III})$ ions showed higher activity against Bacillus subtilis, Serratia species, and Escherichia coli than that the original tetracycline hydrochloride [6]. Platinum(II) complexes of tetracycline 


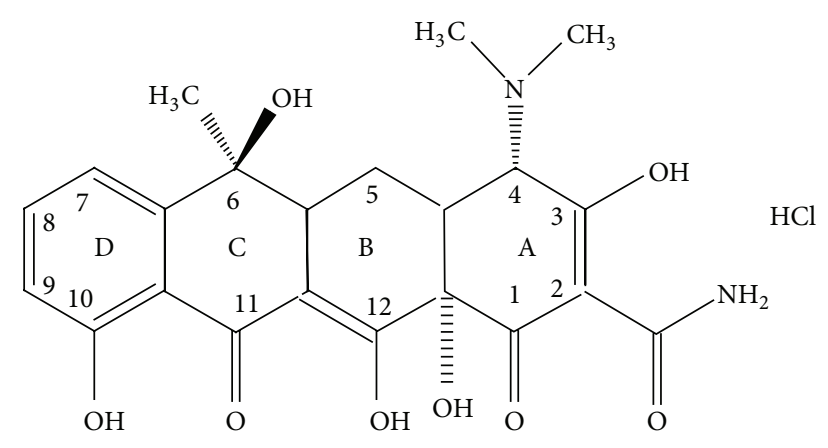

Figure 1: TC. HCl.

and doxycycline were reported to bind to DNA and inhibit tumoral cell growth [15]. Although the $\mathrm{Au}(\mathrm{III})$ is as important as $\mathrm{Pt}(\mathrm{II})$ ions in this aspect, little attention has been paid to $\mathrm{Au}(\mathrm{III})$ complexes of TC. Environmental studies on TCs showed that complexation of these drugs with heavy metal cations in natural waters and soils may induce chronic toxic effects in aquatic plants $[7,8,17]$.

In this work we study the determination of TC (see Figure 1) in pure and dosage form via complexation with gold(III) and mercury(II) ions in solution using UV-visible and atomic absorption spectrophotometry and HPLC techniques.

\section{Experimental}

UV-visible spectra were recorded on Varian Gary 100 UVvisible spectrophotometer supplied with UV-probe software. FTIR spectra were recorded on Shimadzu FT-IR 8400 S Fourier transforms infra-red spectrophotometer. Flame atomic absorption spectrophotometric studies (FAAS) on $\mathrm{Au}(\mathrm{III})$ ion and its complexes were carried out using GBC 933 plus flame atomic absorption spectrophotometer supplied with hollow cathode lamp, $\mathrm{D}_{2}$ Lamp (GBC), flame autosampler, and air-acetylene flame. High performance liquid chromatography was performed on HPLC, Shimadzu, and Shimadzu LC 2010A, supplied with UV-visible detector. HPLC conditions for determination of Tc-Au(III) complexes were : stationary phase or column $150 \times 4.65 \mathrm{~mm}$ supelcosil LC-18, mobile phase acetonitrile:acetate buffer solution $(40: 60)$, flow rate $(1 \mathrm{~mL} / \mathrm{min})$, injection volume $100 \mu \mathrm{L}$, detection wavelength $(220 \mathrm{~nm})$. HPLC conditions for determination of $\mathrm{Hg}(\mathrm{II})-\mathrm{TC}$ complexes were : mobile phase acetonitrile: acetate buffer solution (20:80), stationary phase or column $150 \times 4.65 \mathrm{~mm}$ ODS C-18, flow rate $(2 \mathrm{~mL} / \mathrm{min})$, injection volume $200 \mu \mathrm{L}$, detection wavelength $(276 \mathrm{~nm})$. pH of solutions were measured by using HANA, HI 98150 GLP $\mathrm{PH} / \mathrm{ORP}$-meter calibrated with reference $\mathrm{pH}$ solutions at 4.0 and 9.0.

All chemicals used were of analytical reagent grade, and tetracycline hydrochloride was provided from state company for drug industries, and medical appliance (SDI), Samarra Iraq.

2.1. Antibiotic Standard Solutions. A stock solution of tetracycline hydrochloride (TC. $\mathrm{HCl})(1000 \mu \mathrm{g} / \mathrm{mL})$ was prepared by dissolving $0.100 \mathrm{~g}$ of TC. $\mathrm{HCl}$ standard powder in $100 \mathrm{~mL}$ distilled deionized water (DDW). Working standard solutions of TC. $\mathrm{HCl}(100-150 \mu \mathrm{g} / \mathrm{mL})$ were prepared by diluting $10-15 \mathrm{~mL}$ of stock solution to $100 \mathrm{~mL}$ with DDW in $100 \mathrm{~mL}$ volumetric flask.

2.2. Metal Ions Standard Solutions $(100 \mu \mathrm{g} / \mathrm{mL})$. A stock solution of $\mathrm{Hg}$ (II) ions $(1000 \mu \mathrm{g} / \mathrm{mL})$ was prepared by dissolving $0.1350 \mathrm{~g}$ of $\mathrm{HgCl}_{2}$ in a $100 \mathrm{~mL}(\mathrm{DDW})$ in $100 \mathrm{~mL}$ volumetric flask. Working solutions $(100 \mu \mathrm{g} / \mathrm{mL})$ were prepared by diluting $10 \mathrm{~mL}$ of the stock solution to $100 \mathrm{~mL}$ with DDW in a $100 \mathrm{~mL}$ volumetric flask. Working solutions of $\mathrm{Au}(\mathrm{III})$ ions $(100 \mu \mathrm{g} / \mathrm{mL})$ were prepared from $1000 \mu \mathrm{g} \cdot \mathrm{mL}^{-1} \mathrm{Au}(\mathrm{III})$ solution provided from suppliers for atomic absorption spectrophotometric analysis.

2.3. UV-Visible Spectrophotometry Complex Formation. To $1 \mathrm{~mL}$ aliquots of metal ion solutions $\left(5.08 \times 10^{-3} \mathrm{M}\right)$ in a series of $10 \mathrm{~mL}$ volumetric flasks were added $0.25,0.5,0.75$, $1.0,2.0,3.0$, and $4.0 \mathrm{~mL}$ of TC. HCl solution $\left(5.08 \times 10^{-3} \mathrm{M}\right)$ and volumes were completed to the marks. All experimental conditions were set to their optimum values, and resulting complexes were extracted from aqueous solutions with ethyl acetate $(5: 1 \mathrm{v} / \mathrm{v}$ aq :EA) before measuring the absorbance.

2.3.1. Determination of Antibiotic Complexes by Direct Method. Solution mixtures of $5-70 \mu \mathrm{g} / \mathrm{mL}$ TC. $\mathrm{HCl}$ and $10 \mu \mathrm{g} / \mathrm{mL} \mathrm{Au}$ (III) ion or $15 \mu \mathrm{g} / \mathrm{mL}$ of $\mathrm{Hg}$ (II) standard solutions were prepared by adding different volumes of antibiotics' standard solutions $(100 \mu \mathrm{g} / \mathrm{mL})$ to $1 \mathrm{ml}$ or $1.5 \mathrm{~mL}$, respectively, of metal ion standard solutions $(100 \mu \mathrm{g} / \mathrm{mL})$ in $10 \mathrm{~mL}$ volumetric flasks. The volumes were completed to the mark, and the experimental conditions were adjusted to the respective optimum values of concentration, $\mathrm{pH}$ and temperature, and liquid extraction with ethyl acetate (EA) $(5: 1 \mathrm{v} / \mathrm{v}$ aq: EA). The absorbance of complexes in each case was recorded at the recommended $\lambda_{\max }$ and plotted against the concentration of the cited antibiotic

2.3.2. Determination of Antibiotic Complexes in Dosage Form by Direct Method. $0.1 \mathrm{~g}$ of TC powder obtained from 20 capsules of samacycline $250 \mathrm{mg}$ was weighted and dissolved in $100 \mathrm{~mL}$ distilled water in volumetric flask. Ten $\mathrm{mL}$ of the resulted solution was diluted to $100 \mathrm{~mL}$ by DDW in volumetric flasks. Then 1,2 , and $3 \mathrm{~mL}$ of the end solution were transferred to $10 \mathrm{~mL}$ volumetric flasks containing $1 \mathrm{~mL}$ of $\mathrm{Au}(\mathrm{III})$ or $1.5 \mathrm{~mL}$ of $\mathrm{Hg}$ (II) standard solutions $(100 \mu \mathrm{g} / \mathrm{mL})$, and the volumes were completed to the marks with DDW. After adjusting to the optimum conditions, the absorbance of these solutions was measured against blank solution, and the concentration of the studied analyst was calculated depending upon the respective standard direct calibration curve.

2.3.3. Determination of Antibiotic Complexes in Dosage Form by Standard Addition Method. To a series of solutions containing $1 \mathrm{~mL}$ of $\mathrm{Au}(\mathrm{III})$ or $1.5 \mathrm{~mL}$ of $\mathrm{Hg}(\mathrm{II})$ standard solutions 
$(100 \mu \mathrm{g} / \mathrm{mL})$ and various amounts $0.5-6.0 \mathrm{~mL}$ or $0.5-5.5 \mathrm{~mL}$, respectively, of TC. $\mathrm{HCl}$ standard solutions $\left(100 \mu \mathrm{g} \cdot \mathrm{mL}^{-1}\right)$ was added $1 \mathrm{~mL}$ of dosage antibiotic (samacycline) solutions $\left(100 \mu \mathrm{g} \cdot \mathrm{mL}^{-1}\right)$ in $10 \mathrm{~mL}$ volumetric flasks. The volumes were completed to the marks with DDW. After adjusting the optimum conditions in each case, the absorbance was measured, and the relationship between absorbance and concentration was plotted to construct standard addition curves.

2.4. Flame Atomic Absorption Spectrometry FAAS for Au(III) Complexes. This method was worked out for the determination of dosage TC at the same optimum conditions fixed in the UV-visible method except that the suitable concentration of $\mathrm{Au}(\mathrm{III})$ ion was $6 \mu \mathrm{g} / \mathrm{mL}$.

2.4.1. Determination of TC-Au(III) Complexes by Direct Method. Solution mixtures containing $1-30 \mu \mathrm{g} / \mathrm{mL}$ of TC. $\mathrm{HCl}$ and $6 \mu \mathrm{g} \cdot \mathrm{mL}^{-1}$ of $\mathrm{Au}(\mathrm{III})$ ion were prepared by adding different volumes of antibiotics' standard solutions $(100 \mu \mathrm{g} / \mathrm{mL})$ to $0.6 \mathrm{~mL}$ of $\mathrm{Au}(\mathrm{III})$ ion standard solution $(100 \mu \mathrm{g} / \mathrm{mL})$ in $10 \mathrm{~mL}$ volumetric flasks. The volumes were completed to the mark and the experimental conditions were adjusted. The absorbance was measured, and the relationship between absorbance and concentration was plotted to produce standard direct calibration curve

2.4.2. Determination of TC-Au(III) Complexes in Dosage Form by Direct Method. From a prepared solution of dosage TC $(100 \mu \mathrm{g} / \mathrm{mL}) 0.6,0.8$, and $1.0 \mathrm{~mL}$ were transferred to $10 \mathrm{~mL}$ volumetric flasks, containing $0.6 \mathrm{~mL}$ of $\mathrm{Au}(\mathrm{III})$ standard solution $(100 \mu \mathrm{g} / \mathrm{mL})$. The volumes were completed to the marks, and all optimum conditions were adjusted. The absorbance of these solutions against blank solution was measured, and the concentrations of solutions were calculated depending on standard calibration curve.

2.4.3. Determination of TC-Au(III) Complexes in Dosage Form by Standard Addition Method. In this method $0.6 \mathrm{~mL}$ of dosage TC $(100 \mu \mathrm{g} / \mathrm{mL})$ solutions was added to aqueous solutions containing a mixture of $0.6 \mathrm{~mL} \mathrm{Au}(\mathrm{III})$ standard solutions $(100 \mu \mathrm{g} / \mathrm{mL})$ and different volumes of TC. $\mathrm{HCl}$ standard solutions to form $1-25 \mu \mathrm{g} / \mathrm{mL}$ solutions. After all optimum conditions have been adjusted, the relationship between absorbance and concentration was plotted to produce standard addition curves for determination of TC in dosage form.

2.5. High Performance Liquid Chromatography (HPLC). Solutions were prepared as was mentioned in the direct UVspectrophotometric method but with different concentration ranges of standard TC. $\mathrm{HCl}(10-150 \mu \mathrm{g} / \mathrm{mL})$ and without solvent extraction. The peak area of complexes was plotted against antibiotic concentration to construct the direct calibration curves.

2.5.1. Determination of Dosage TC Au(III) and Hg(II) Complexes by Direct HPLC Method. A powder of 20 capsules $(0.1 \mathrm{~g})$ was weighted and dissolved in $(100 \mathrm{~mL})$ DDW in a volumetric flask. Twenty-five $\mathrm{mL}$ of this solution was diluted to $100 \mathrm{~mL}$ with DDW in a $100 \mathrm{~mL}$ volumetric flask. Then 1.2, 2.0, and $4.0 \mathrm{~mL}$ of the end solution were transferred to $(10 \mathrm{~mL})$ volumetric flasks containing $1.0 \mathrm{~mL}$ of $\mathrm{Au}(\mathrm{III})$ or $1.5 \mathrm{~mL}$ of $\mathrm{Hg}(\mathrm{II})$ standard solutions $(100 \mu \mathrm{g} / \mathrm{mL})$. The volumes were completed to the marks, and all optimum conditions were adjusted. Peak area of these solutions was measured, and the concentration of solutions was calculated depending on standard direct calibration curve.

\section{Result and Discussion}

3.1. UV-Visible Spectrophotometry. The UV-visible spectra of TC. $\mathrm{HCl}$, metal ions, and their complexes $\left(50 \mu \mathrm{g} \cdot \mathrm{mL}^{-1}\right)$ in aqueous solutions are shown in Figure 2. The spectrum of the drug exhibited a multiplet with maximum absorption peaks at $\lambda 235,270$, and $370 \mathrm{~nm}$ corresponding mainly to $\pi \rightarrow \pi^{*}$ transitions [18]. The spectrum of the yellow gold(III) aqueous solution exhibited two absorption bands, a doublet appeared at $\lambda 240$ and $295 \mathrm{~nm}$ and a low intensity band at $385 \mathrm{~nm}$ and were assigned to ligand to metal charge transfer and ${ }^{1} A_{1} g \rightarrow$ ${ }^{1} \mathrm{Eg}$ transitions of square planar tetrachloroaurate(III) anion $\left[\mathrm{AuCl}_{4}\right]^{-}$[19]. The spectrum of the $\mathrm{Hg}$ (II) ion exhibited a single high intensity band at $\lambda 285 \mathrm{~nm}$ and was assigned to ligand $\rightarrow$ metal charge transfer [19]. The spectrum of TC. $\mathrm{HCl}$ with the $\mathrm{Au}(\mathrm{III})$ ion exhibited hypsochromic shift of the $\pi \rightarrow \pi^{*}$ transitions band and the appearance of two new absorption bands at $\lambda_{\max } 350$ and $425 \mathrm{~nm}$ assigned to ${ }^{1} A_{1} g \rightarrow{ }^{1} \mathrm{Eg}$ and ${ }^{1} A_{1} g \rightarrow{ }^{1} B_{2} g$ transitions of square planar gold(III) complexes, respectively $[16,19,20]$. The spectrum of the $\mathrm{Hg}(\mathrm{II})$ complex solution exhibited shifts of ligand bands to shorter wavelengths and the appearance of additional band at $\lambda_{\max } 320 \mathrm{~nm}$ attributed to ligand to metal charge transfer transition $[16,19,20]$.

3.1.1. Optimisation of the Experimental Conditions. Figure 3 shows the effect of metal ion concentration, $\mathrm{pH}$ of solution, temperature, and heating time on the absorbance of the TC-Au(III) and TC-Hg(II) complex solutions at $\lambda_{\max } 425$ and $320 \mathrm{~nm}$, respectively, using $50 \mu \mathrm{g} / \mathrm{mL}$ of drug solutions. The optimum concentration of the ions that gave maximum absorbance was $10 \mu \mathrm{g} / \mathrm{mL}$ of $\mathrm{Au}$ (III) ions and $15 \mu \mathrm{g} / \mathrm{mL}$ of $\mathrm{Hg}$ (II) ions. The best values of $\mathrm{pH}$ recorded for the highest absorbance values were $2-4$. At high $\mathrm{pH}$ values formation of metal hydroxides took place $[21,22]$. It is also important to mention that tetracycline is a very adaptive molecule, capable of easily modifying itself through tautomerism in response to various chemical environments [10, 23-25]. Therefore protonation and deprotonation of Tcs in acidic and basic aqueous solutions have important effects on their coordination behavior and their absorption spectra $[23,24]$. However the hypsochromic shift of the $\pi \rightarrow \pi^{*}$ transitions band in this study supports the suggested structures of $\mathrm{Au}(\mathrm{III})$ and $\mathrm{Hg}$ (II) complexes [16]. The extraction efficiency and the choice of extracting solvent have also an important effect on absorbance values [26, 27]. Optimum experimental conditions for TC. $\mathrm{HCl}$ complexes with $\mathrm{Au}(\mathrm{III})$ and $\mathrm{Hg}$ (II) ions are described in Table 1. 


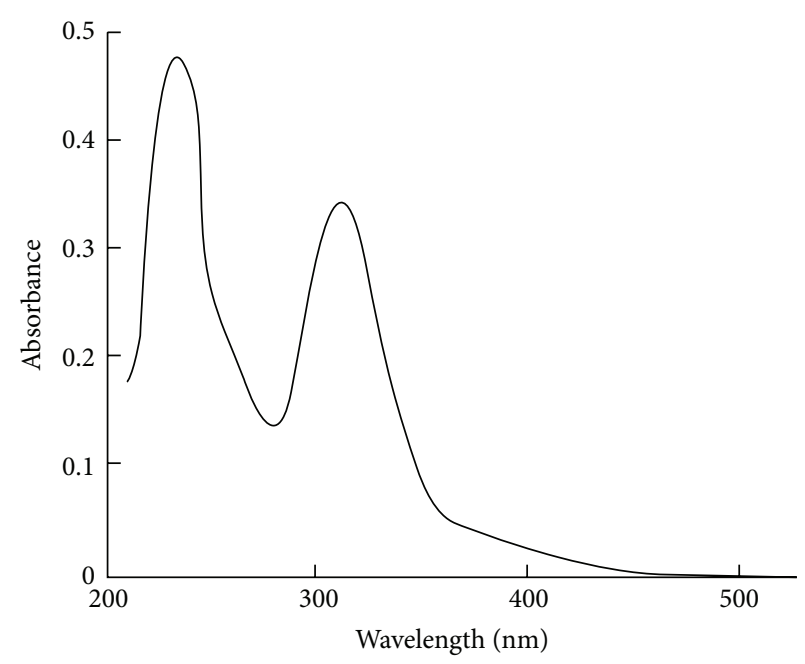

(a)

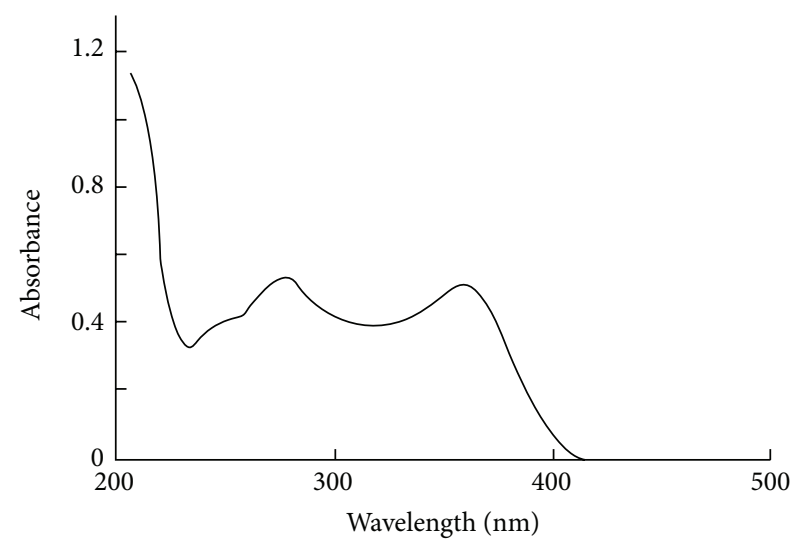

(c)

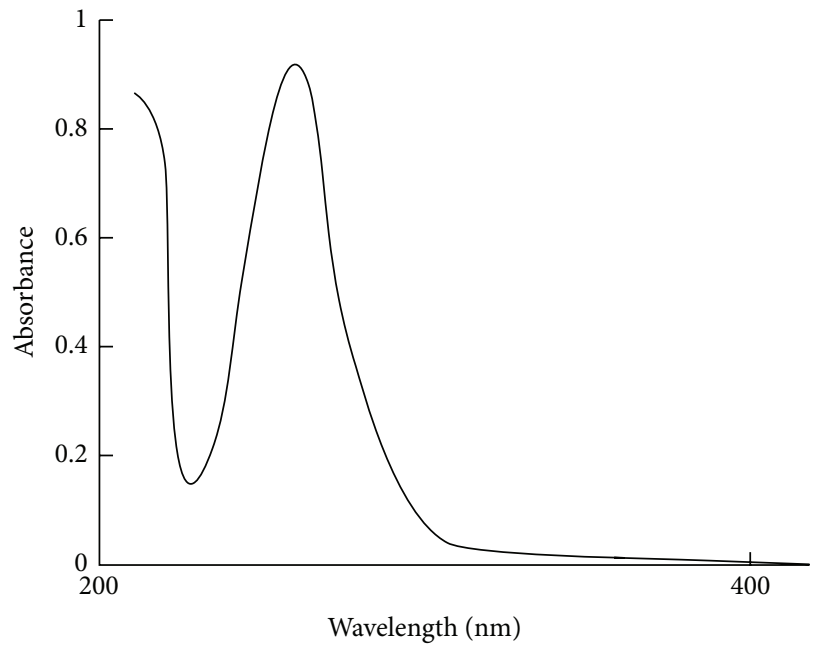

(b)

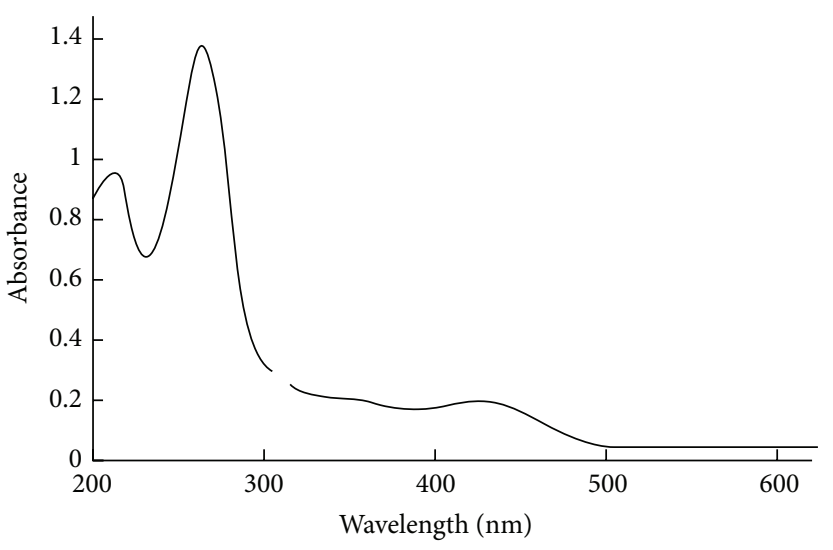

(d)

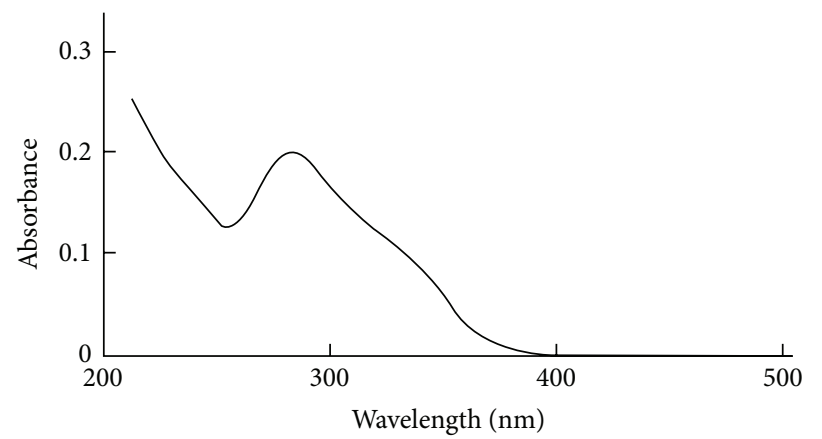

(e)

Figure 2: UV-visible spectra of (a) gold(III) ion, (b) mercury(II) ion, (c) TC. HCl, (d) TC-Au(III), and (e) TC-Hg(II) complexes in aqueous solutions $(50 \mu \mathrm{g} / \mathrm{mL}$ each).

TABLE 1: Optimum experimental conditions for TC. $\mathrm{HCl}$ complexes with $\mathrm{Au}(\mathrm{III})$ and $\mathrm{Hg}(\mathrm{II})$ ions.

\begin{tabular}{lcccccccc}
\hline Complex & $\begin{array}{c}\text { Ion conc. } \\
(\mu \mathrm{g} / \mathrm{mL})\end{array}$ & $\mathrm{pH}$ & $\begin{array}{c}\text { Heating temp. } \\
\left({ }^{\circ} \mathrm{C}\right)\end{array}$ & $\begin{array}{c}\text { Heating time } \\
(\text { min. })\end{array}$ & $\begin{array}{c}\text { Phase ratio } \\
(\mathrm{EA}: \mathrm{aq})\end{array}$ & $\begin{array}{c}\text { Extraction time } \\
(\mathrm{min})\end{array}$ & $\begin{array}{c}\text { Extraction\% } \\
(E \%)\end{array}$ & $\begin{array}{c}\text { Distribution } \\
\text { ratio }\end{array}$ \\
\hline TC-Au & 10 & 4 & 75 & 15 & $1: 5$ & 1 & 95.242 \\
TC-Hg & 15 & $2-4$ & 75 & 15 & $1: 5$ & $1-2$ & 100.196 \\
\hline
\end{tabular}




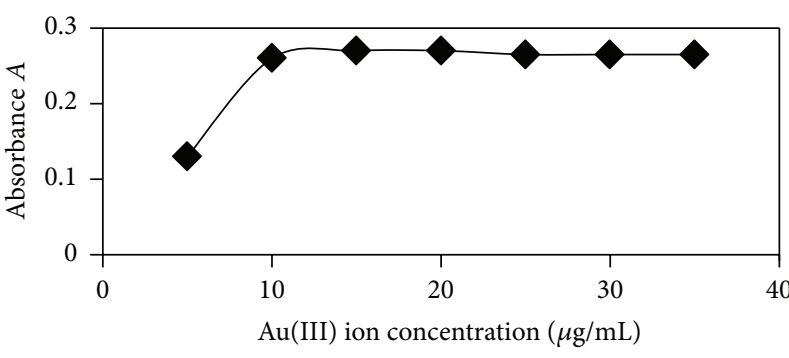

(a)

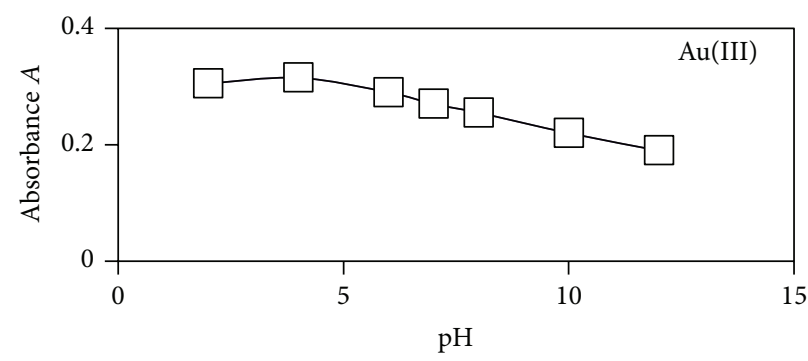

(c)

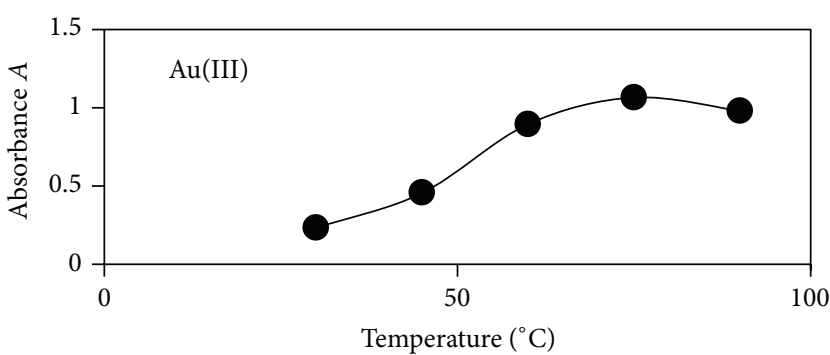

(e)

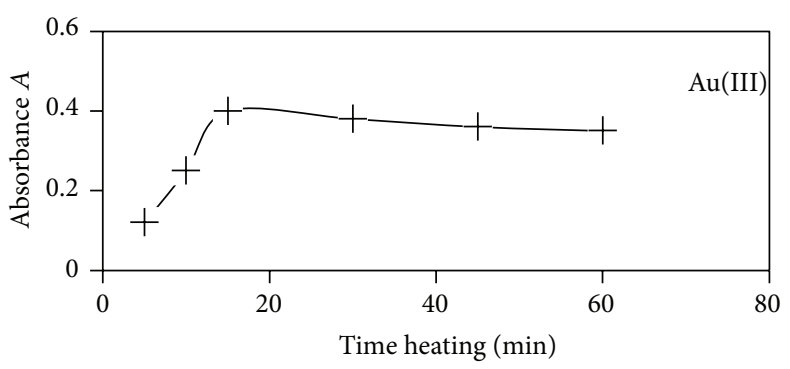

(g)

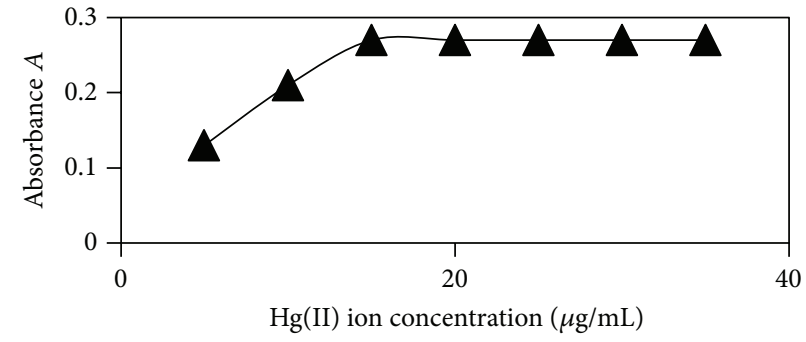

(b)

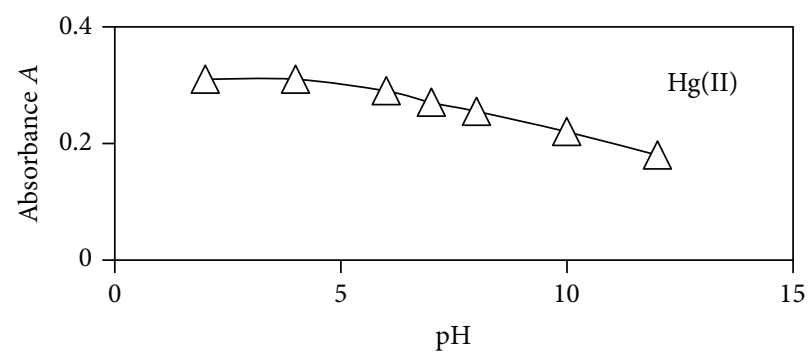

(d)

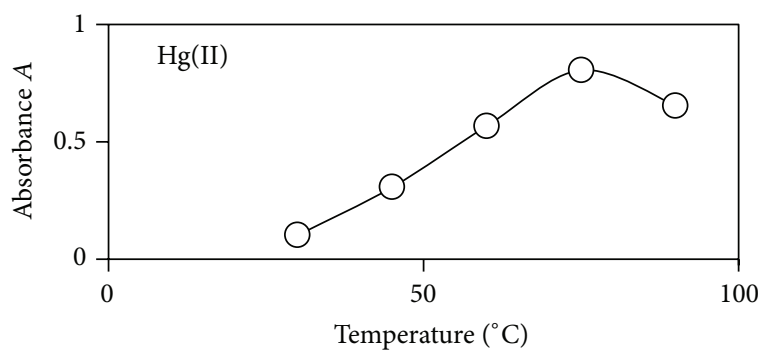

(f)

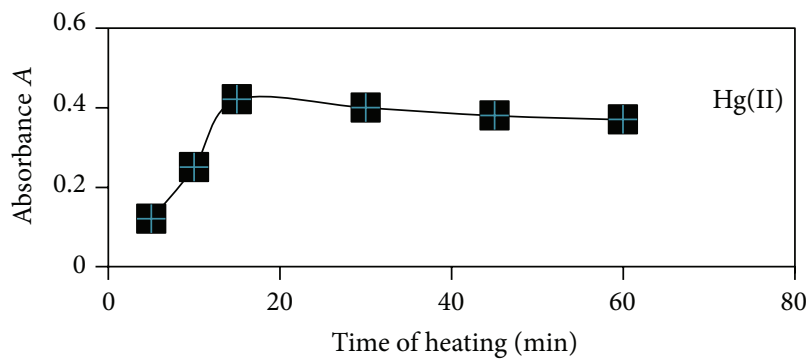

(h)

FIGURE 3: Optimum absorbance conditions for tetracycline $\mathrm{Au}(\mathrm{III})$ and $\mathrm{Hg}$ (II) complexes.

TABLE 2: Stability constant $(k)$ and molar absorptivity for TC-Au(III) and $\mathrm{TC}-\mathrm{Hg}(\mathrm{II})$ complexes in solutions.

\begin{tabular}{lccc}
\hline Complex & $\begin{array}{c}\varepsilon_{\max } \\
\left(\mathrm{L}_{\mathrm{mol}} \mathrm{mol}^{-1} \cdot \mathrm{cm}^{-1}\right)\end{array}$ & $\begin{array}{c}\text { Stability constant }(k) \\
\left(\mathrm{M}^{-1}\right)\end{array}$ & $\begin{array}{c}\lambda_{\max } \\
(\mathrm{nm})\end{array}$ \\
\hline TC-Au(III) & $3.4820 \times 10^{3}$ & $2.5187 \times 10^{4}$ & 425 \\
TC-Hg(II) & $6.9656 \times 10^{3}$ & $1.6122 \times 10^{5}$ & 320 \\
\hline
\end{tabular}

Figure 4 shows the effect of volume ratio of complex aqueous solution to ethyl acetate (aq: EA or aq: org.), extraction percentage, and extraction time on the absorbance of complexes. The highest absorbance value was achieved when the ratio of aqu: EA was $5: 1$. The percentage of extraction $(\% E)$ and distribution ratio $(D)$ were obtained from following equations [27]:

$$
\begin{gathered}
\% E=\frac{\text { Initial Conc. }(\text { org. })-\text { Final Conc. }(\mathrm{aq})}{\text { Initial Conc. }(\text { org. })} \times 100, \\
\% E=\frac{100 D}{D+\left(V_{\mathrm{aq}} / V_{o}\right)},
\end{gathered}
$$

where $V_{\mathrm{aq}}$ and $V_{o}$ are volumes of aqueous and organic layers, respectively. 


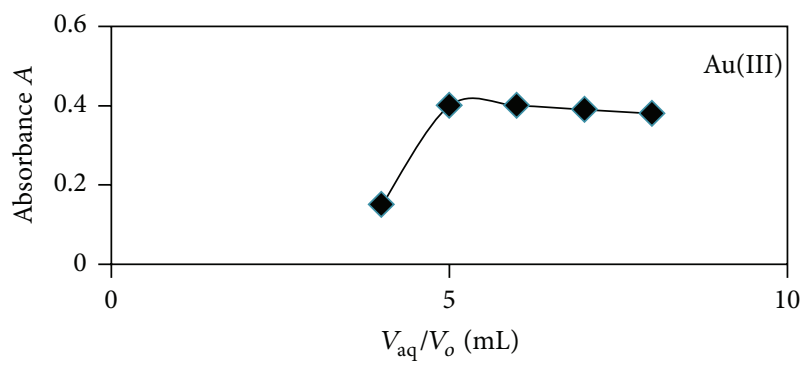

(a)

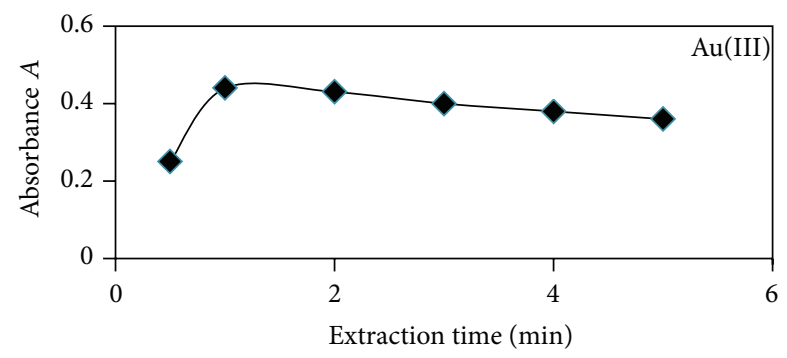

(c)

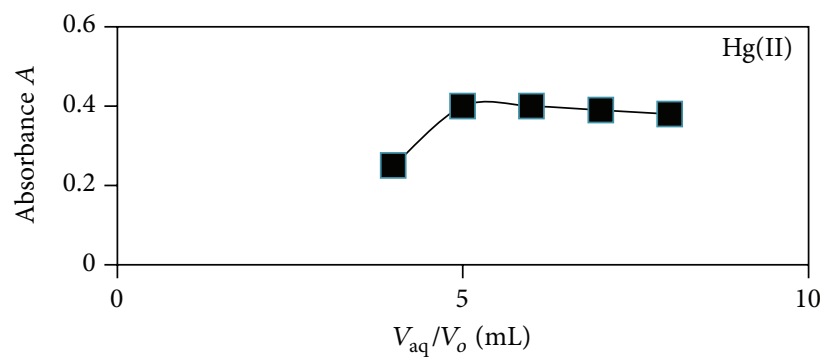

(b)

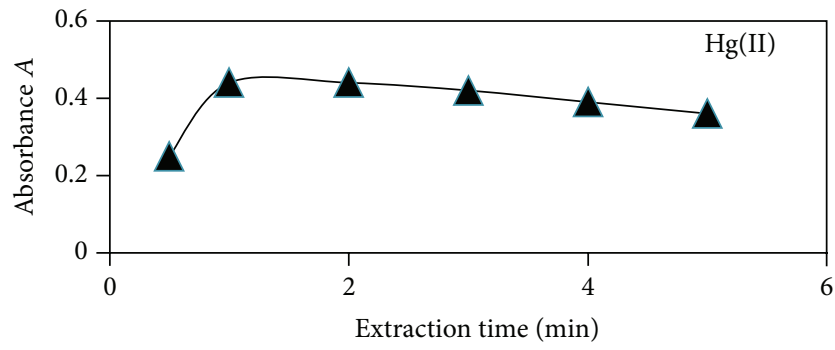

(d)

FIGURE 4: Phase ratio of aq: EA $\left(V_{\mathrm{aq}} / V_{o}\right)$ extraction effect and extraction time effects on absorbance of TC-Au(III) and TC-Hg(II) complexes.

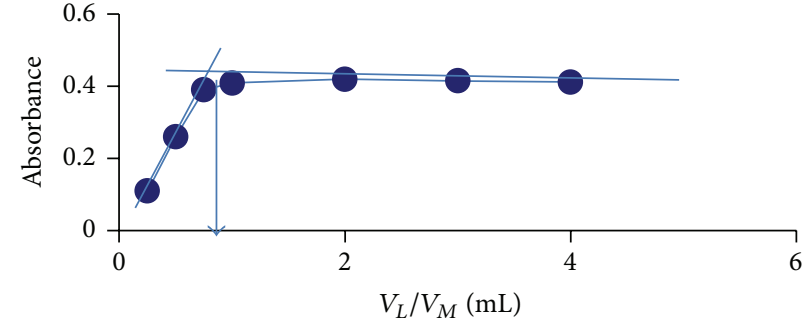

(a)

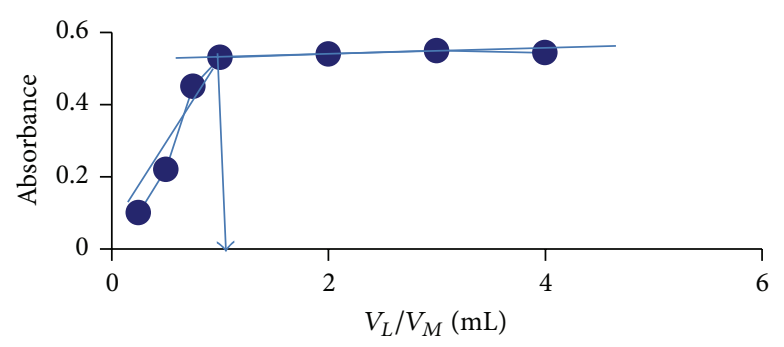

(b)

FIgURE 5: The mole ratio curves for the formation of (a) TC-Au(III) and (b) TC-Hg(II) complexes in solutions at optimum conditions.

TABLE 3: Regression equation, correlation coefficient, $t$-test concentration ranges, detection limits, and RSD\% direct and standard addition calibration curves of TC-Au complex by using uv-visible spectrophotometry.

\begin{tabular}{|c|c|c|c|c|c|c|c|c|}
\hline Method & $\begin{array}{c}\text { Regr. eq. } \\
Y=B x+A\end{array}$ & $\begin{array}{l}\text { Correlation } \\
\text { coefficient }(r)\end{array}$ & $\begin{array}{l}\text { Line range } \\
(\mu \mathrm{g} / \mathrm{mL})\end{array}$ & $\begin{array}{c}\text { D.L. } \\
(\mu \mathrm{g} / \mathrm{mL})\end{array}$ & $\begin{array}{l}t \text {-test statistic } \\
\quad(\text { calcd })\end{array}$ & $\begin{array}{c}\text { Tabulated } \\
t \text {-test two } \\
\text { tailed } 95 \% \text { C.I. }\end{array}$ & $\begin{array}{l}\mathrm{RSD} \% \\
(n=4)\end{array}$ & $\begin{array}{l}\text { Mean } \\
\text { Rec.\% }\end{array}$ \\
\hline \multicolumn{9}{|l|}{ TC-Au(III) complex } \\
\hline Direct & $Y=0.0093 x-0.0080$ & 0.9991 & $5-70$ & 0.7403 & 0.3994 & 2.365 & 0.9617 & 100.780 \\
\hline Standard addition & $Y=0.0115 x+0.1133$ & 0.9989 & $5-70$ & & 0.8320 & 2.365 & 1.2855 & 103.970 \\
\hline \multicolumn{9}{|l|}{ TC-Hg(II) complex } \\
\hline Direct & $Y=0.0100 x-0.037$ & 0.9989 & $5-70$ & 0.5867 & 0.4791 & 2.365 & 0.9617 & 100.950 \\
\hline Standard addition & $Y=0.0102 x+0.0963$ & 0.9986 & $5-70$ & & 1.2126 & 2.365 & 1.2854 & 103.103 \\
\hline
\end{tabular}

TABLE 4: Percentage relative error for determination of TC-Au(III) and TC-Hg(II) complexes by direct and standard addition UV-vis methods.

\begin{tabular}{|c|c|c|c|c|c|c|}
\hline Complex & State of drug & $\begin{array}{c}\text { Stated concentration } \\
\text { (mg/unit) }\end{array}$ & $\begin{array}{l}\text { Found direct calb. } \\
\text { (mg/unit) }\end{array}$ & \% Erel & $\begin{array}{l}\text { Found st. add. calb. } \\
\text { (mg/unit) }\end{array}$ & $\%$ Erel \\
\hline TC-Au(III) & Capsule & 250 & 251.950 & +0.780 & 259.925 & +3.970 \\
\hline TC-Hg(II) & Capsule & 250 & 252.375 & +0.950 & 257.757 & +3.103 \\
\hline
\end{tabular}


TABLE 5: Regression equation, correlation coefficient, $t$-test concentration ranges, detection limits, RSD\%, and recovery (rec.\%) for the determination of TC-Au(III) complex by FAAS.

\begin{tabular}{|c|c|c|c|c|c|c|c|}
\hline $\begin{array}{l}\text { Regr. eq. } \\
Y=B x+A\end{array}$ & $\begin{array}{c}\text { Corr. } \\
\text { coefficient }(r)\end{array}$ & $\begin{array}{c}\text { Linear range } \\
(\mu \mathrm{g} / \mathrm{mL})\end{array}$ & $\begin{array}{c}\text { D.L. } \\
(\mu \mathrm{g} / \mathrm{mL})\end{array}$ & $\begin{array}{l}t \text {-test statistic } \\
\quad(\text { calcd })\end{array}$ & $\begin{array}{c}\text { Tabulated } \\
t \text {-test two tailed 95\% C.I. }\end{array}$ & $\begin{array}{l}\mathrm{RSD} \% \\
(n=4)\end{array}$ & Rec.\% \\
\hline \multicolumn{8}{|l|}{ Direct method } \\
\hline$Y=0.0520 x+0.0088$ & 0.9967 & $5-30$ & 0.0995 & 1.7603 & 2.571 & 1.054 & 104.753 \\
\hline \multicolumn{8}{|c|}{ Standard addition method } \\
\hline$Y=00549 x+0.2791$ & 0.9988 & $5-28$ & & 0.6569 & 2.571 & 3.253 & 95.639 \\
\hline
\end{tabular}<smiles>CN(C)[C@H]1C(O)=C(C(N)=O)C(=O)[C@@]2(O)C(O)=C3C(=O)c4c(O)cccc4[C@@](C)(O)C3CC12</smiles><smiles>CN(C)[C@H]1C(O)=C(C(N)=O)C(=O)[C@@]2(O)C(O)=C3C(=O)c4c(O)cccc4[C@@](C)(O)C3C[C@H]12</smiles>

Figure 6: The suggested structures of TC-Au(III) and TC-Hg(II) complexes.

3.1.2. Complex Formation by Mole Ratio Method and Calculation of Stability Constant $(k)$ of Complexes. Figure 5 shows the variation of absorbance of TC-Au(III) and TC$\mathrm{Hg}$ (II) complexes against mole ratio of TC: $\mathrm{M}\left(5.8 \times 10^{-3} \mathrm{M}\right.$ each). The ratios for both complexes were $1: 1$. The stability constant values for both complexes (Table 2) were calculated depending on mole ratio curves according to the equation

$$
k=\frac{\left(A_{1}-A_{3}\right)\left(A_{2}-A_{3}\right)}{\left(A_{2}-A_{1}\right)^{2} C},
$$

where $k$ is the formation constant, $C$ is the molar concentration, $A_{1}$ is the absorbance which represents two tangents intercept, $A_{2}$ is the absorbance which represents the highest absorbance, $A_{3}$ is the absorbance of first point.

3.1.3. Suggested Structures. The results of UV-visible and IR spectra, conductivity measurements, and metal content obtained from the synthesis of the two complexes in the solid state [28] led to the suggested structure illustrated in Figure 6 and supported the results of complex formation in solution. The IR spectrum of the free TC. $\mathrm{HCl}$ showed two absorption bands at $3280-3480 \mathrm{~cm}^{-1}$ attributed to $\mathrm{O}-\mathrm{H}$ stretching vibrations that undergo intermolecular hydrogen bonding $[6,15]$. This band was shifted to higher frequencies at $3379-3439 \mathrm{~cm}^{-1}$ and to $3340-3440 \mathrm{~cm}^{-1}$ in the spectra of $\mathrm{Au}(\mathrm{III})$ and $\mathrm{Hg}(\mathrm{III})$ complexes, respectively, which rules out the coordination of the hydroxyl group with the two metal ions. The band observed at $3122 \mathrm{~cm}^{-1}$ was attributed to $\nu \mathrm{NH}$ of amide group [3]. The bands observed at 1672, 1618.2 , and $1583 \mathrm{~cm}^{-1}$ in the spectrum of TC. $\mathrm{HCl}$ are characteristic of amide carbonyl, carbonyl groups of rings $\mathrm{A}$ and $\mathrm{C}$, respectively [17]. Complexation of TC with $\mathrm{Au}(\mathrm{III})$ and $\mathrm{Hg}(\mathrm{II})$ ions caused shifts of the amide $\mathrm{C}=\mathrm{O}$ and ring $\mathrm{A} \mathrm{C}=\mathrm{O}$ to lower frequencies at $1639.55,1608$, and $1637.6,1599 \mathrm{~cm}^{-1}$, respectively. This provides a strong evidence on bonding of the two carbonyls with the two ions [16]. Stretching modes of $\mathrm{M}-\mathrm{O}$ bonds related to the two carbonyls were observed at 555, 525 and 550, 520 for the two complexes respectively. The new bands appeared at $324,315 \mathrm{~cm}^{-1}$ and $317,312 \mathrm{~cm}^{-1}$ may be assigned to stretching vibrations of $\mathrm{Au}-\mathrm{Cl}$ and $\mathrm{Hg}-\mathrm{Cl}$, respectively [6]. 


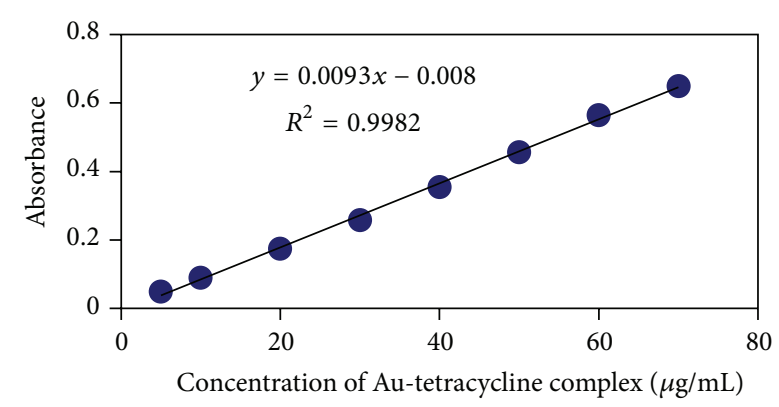

(a)

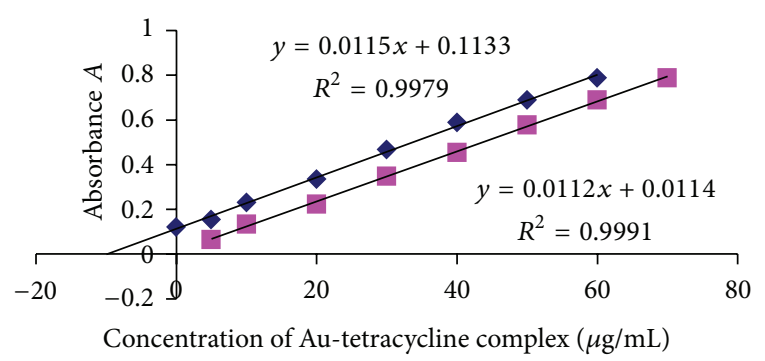

(b)

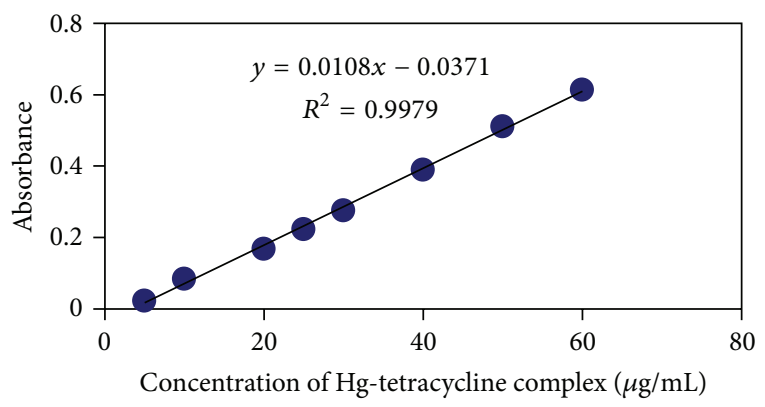

(c)

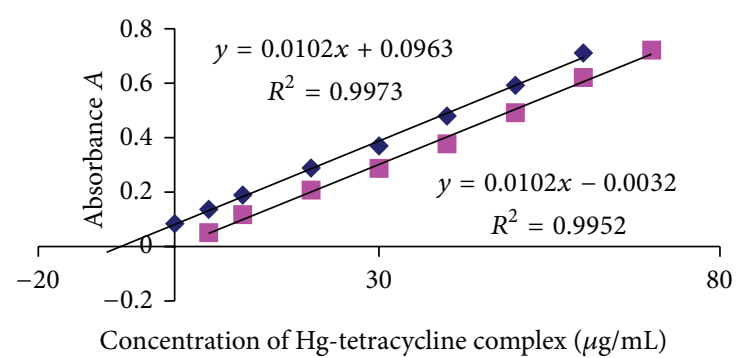

(d)

FIgURE 7: Direct and standard addition calibration curves for determination of $\mathrm{TC}-\mathrm{Au}(\mathrm{III})$ and $\mathrm{TC}-\mathrm{Hg}(\mathrm{II})$ complexes by spectrophotometric methods at $\lambda_{\max } 425$ and $320 \mathrm{~nm}$, respectively.

3.1.4. Determination of TC-Au(III) and TC-Hg(II) Complexes by UV-Vis Method. Figure 7 shows the direct and standard addition calibration curves of absorbance against concentration for determination TC-Au(III) and TC-Hg(II) complexes. The analytical parameters described in Tables 3 and 4 were calculated depending on these curves. Table 3 show that $t$ tabulated is more than $t$-calculated which indicates that the results of the slope of standard addition curve were parallel to slope of direct method which means that there was no
TABLE 6: Relative error percentage for determination of TC-Au complex by direct and standard addition FAAS method.

\begin{tabular}{lcccc}
\hline Method & $\begin{array}{c}\text { State of } \\
\text { drug }\end{array}$ & $\begin{array}{c}\text { Stated } \\
\text { concentration } \\
\text { (mg per unit) }\end{array}$ & $\begin{array}{c}\text { Found } \\
\text { (mg per unit) }\end{array}$ & Erel.\% \\
\hline $\begin{array}{l}\text { Direct } \\
\begin{array}{l}\text { Standard } \\
\text { addition }\end{array}\end{array}$ & Capsule & 250 & 261.883 & +4.753 \\
\hline
\end{tabular}

matrix interference of additives on absorbance of complexes [29]. The correlation coefficient values are within the accepted ranges. The high range of concentration and low detection limits show that the adopted method is applicable and reliable. The RSD\% and percentage relative errors (Table 4) for the determination of the two complexes by direct method were less than those of standard addition methods.

3.2. Determination of Drug-Au Complexes by Direct FAAS Method. The flame atomic absorption spectroscopy was applied for determination of drugs indirectly by determination of gold(III) ions in the extracted complexes depending on direct and standard addition curves of absorbance of $\mathrm{Au}(\mathrm{III})$ complex against TC concentrations (Figure 8). Tables 5 and 6 describe the calculated analytical data obtained from the two curves. Compared with the UV-visible method, this method showed similar percentage recovery, lower concentration range, and higher percentage error (Table 6). However, the percentage recovery was comparable to that obtained for the determination of other drugs by $\mathrm{Au}(\mathrm{III})$ ion [30]. On the other hand this method showed very low detection limit which makes it more sensitive than the UVvisible method.

The $t$-test calculated values are much lower than $t$ tabulated, and the slopes of standard addition curves were also parallel to slopes of direct calibration curve, which indicates that the results of the applied method are acceptable with no matrix interference effect observed [26, 29].

3.3. Determination of TC Complexes by (HPLC) Method. This method was applied for the determination of TC and its complexes directly and simultaneously. Figure 9 shows the HPLC chromatograms in which the retention time for the parent ligand and metal complexes was obtained simultaneously at detection wavelength without solvent extraction because HPLC is a separation technique. Tables 7 and 8 describe the results obtained from direct calibration curves by plotting peak area of complexes against concentration. In spite of higher detection limits the $t$-test, linearity, and correlation coefficients indicate that the applied method is acceptable besides being faster and easier than the other two previous methods. The detection limits and sensitivity may be improved by finding a better separation conditions [29].

\section{Conclusions}

Tetracycline is a very adaptive molecule, capable of easily modifying itself (chemical bonds as well as geometry) 


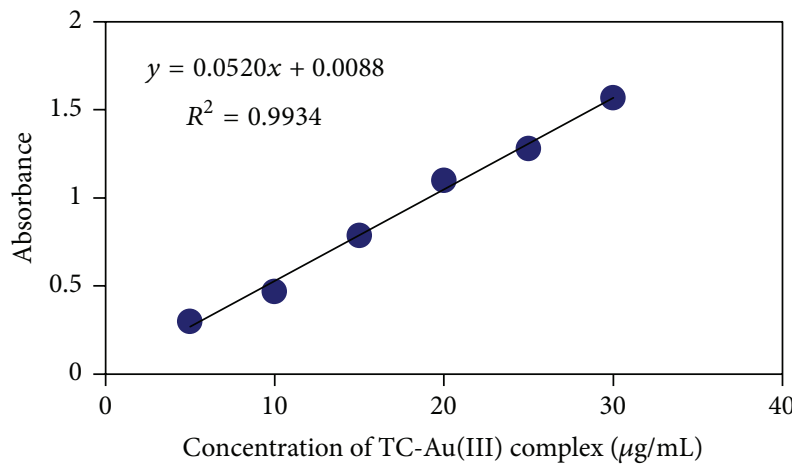

(a)

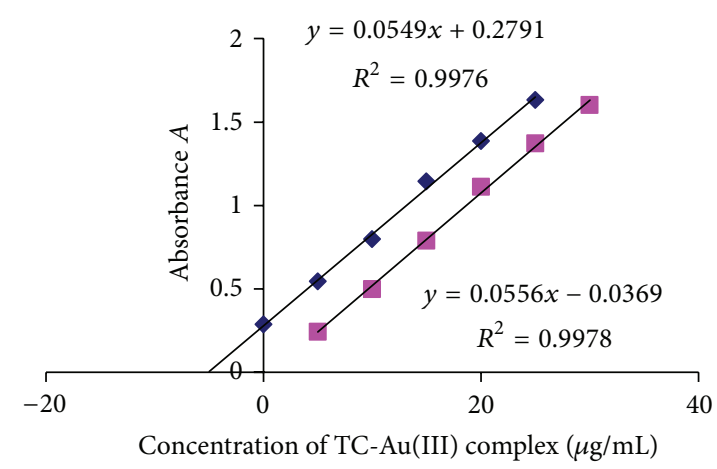

(b)

FIgURE 8: Direct and standard addition calibration curves for TC-Au(III) complex by FAAS.

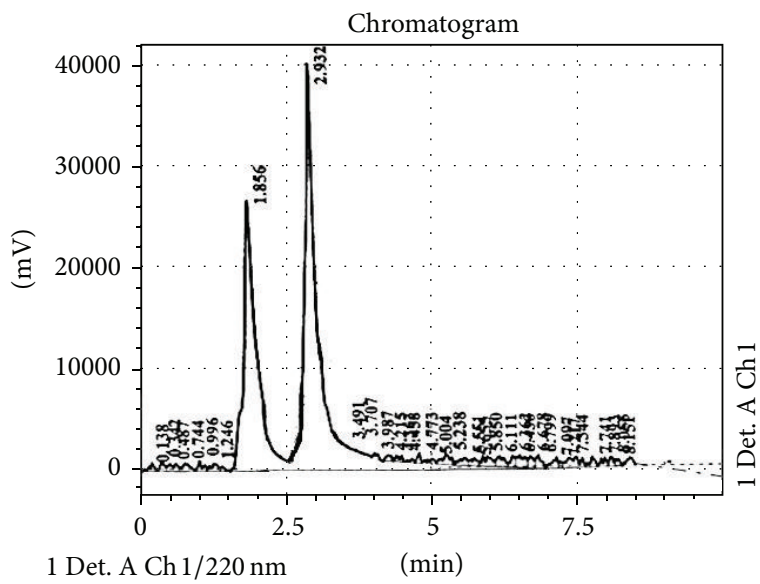

(a)

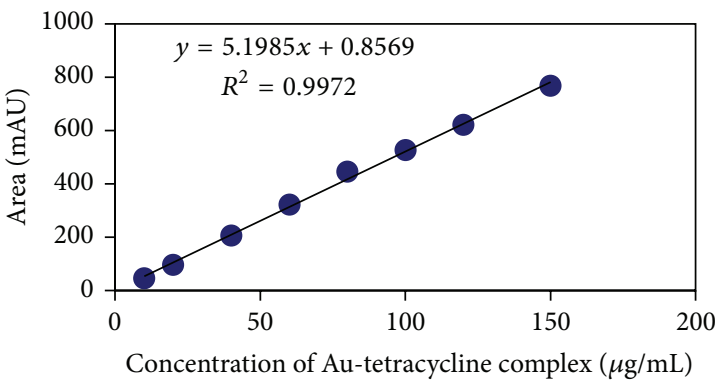

(c)

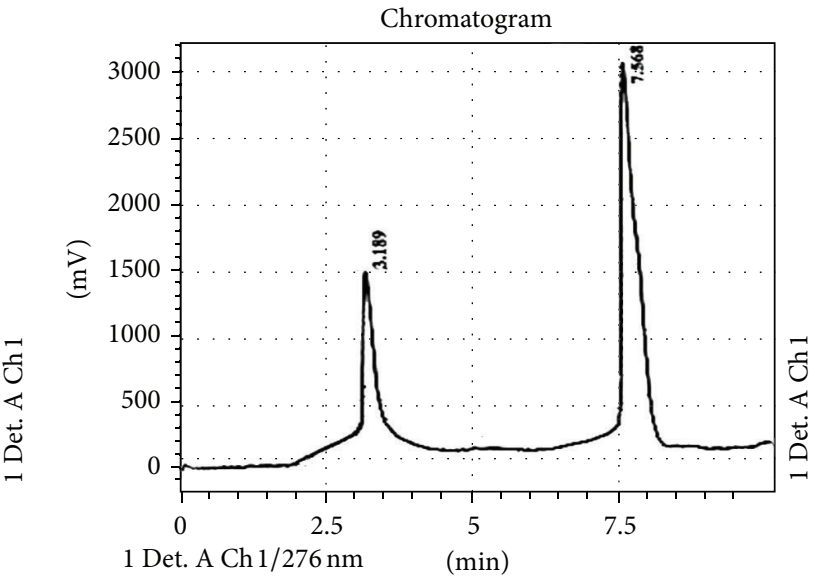

(b)

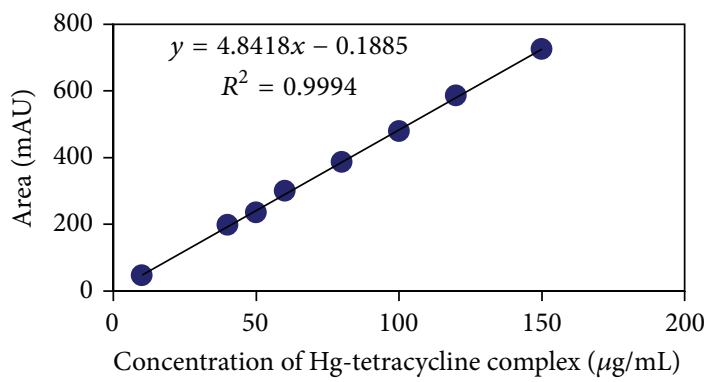

(d)

Figure 9: Upper: chromatograms of TC and its (a) $\mathrm{Au}(\mathrm{III})$ and (b) $\mathrm{Hg}$ (II) complexes with retention times (1.865, 2.932 min) and (3.189, $7.568 \mathrm{~min}$ ), respectively, at detection $\lambda_{\max } 220$ and $276 \mathrm{~nm}$, respectively. Lower: direct calibration curves for the determination of TC-Au(III) and TC-Hg(II) complexes by HPLC method.

TABLE 7: Regression equation, correlation coefficient, $t$-test concentration ranges, detection limits, and RSD\% for TC-Au(III) and TC-Hg(II) complexes by HPLC.

\begin{tabular}{|c|c|c|c|c|c|c|c|}
\hline $\begin{array}{l}\text { Regr. eq. } \\
Y=B x+A\end{array}$ & $\begin{array}{c}\text { Correlation } \\
\text { coefficient }(r)\end{array}$ & $\begin{array}{l}\text { Linear range } \\
(\mu \mathrm{g} / \mathrm{mL})\end{array}$ & $\begin{array}{c}\text { D.L. } \\
(\mu \mathrm{g} / \mathrm{mL})\end{array}$ & $\begin{array}{c}t \text {-tests statistic } \\
\text { (calculated) }\end{array}$ & $\begin{array}{l}\text { Tabulated } t \text {-test two } \\
\text { tailed 95\% C.I. }\end{array}$ & $\begin{array}{l}\mathrm{RSD} \% \\
(n=4)\end{array}$ & Rec.\% \\
\hline \multicolumn{8}{|l|}{ TC-Au(III) complex } \\
\hline$Y=5.1985 x+0.8569$ & 0.9986 & $10-150$ & 2.647 & 1.2864 & 2.365 & 1.2339 & 101.777 \\
\hline \multicolumn{8}{|l|}{ TC-Hg(II) complex } \\
\hline$Y=4.8418 x-0.1885$ & 0.9997 & $10-150$ & 2.532 & 1.4720 & 2.365 & 1.0733 & 102.000 \\
\hline
\end{tabular}


TABLE 8: Relative percentage error for determination of TC-Au(III) and TC-Hg(II) complexes by HPLC direct method.

\begin{tabular}{lcccc}
\hline Complex & State of drug & $\begin{array}{c}\text { Stated } \\
\text { concentration } \\
\text { (mg/unit) }\end{array}$ & $\begin{array}{c}\text { Found } \\
\text { (mg/unit) }\end{array}$ & \% Erel. \\
\hline TC-Au(III) & Capsule & 250 & 254.4425 & +1.777 \\
TC-Hg(II) & Capsule & 250 & 255.000 & +2.000 \\
\hline
\end{tabular}

through tautomerism in response to various chemical environments which have a strong effect on its coordination behavior with metal ion and consequently on the determination method. UV-visible absorption spectrophotometry, flame atomic absorption spectrophotometry FAAS, and high performance liquid chromatography HPLC have been applied successfully to determine the antibiotic (tetracycline hydrochloride) in pharmaceutical preparations by studying, for the first time, the complexation behavior of this drug with gold(III) and mercury(II) ions in solutions. The results of mole-ratio in solution at $\mathrm{pH} 4$ agreed with the suggested square planar and tetrahedral structural formula for the solid $\mathrm{Au}(\mathrm{III})$ and $\mathrm{Hg}(\mathrm{II})$ chelate complexes, respectively. The FTIR spectra showed that TC coordinates with the metal ions through amide $\mathrm{C}=\mathrm{O}$ and ring $\mathrm{A} \mathrm{C}=\mathrm{O}$ showing bidentate behavior. The results of comparison between FAAS, UV-visible spectrophotometry, and HPLC methods for the studied chelate complexes showed that the FAAS method, although of higher cost, showed higher sensitivity, lower detection limits, and linear ranges than UV-visible spectrophotometry and HPLC techniques. The HPLC method showed high detection limits but also high linear range and less time consumption for analysis by omitting the extraction step compared with the other two methods.

\section{References}

[1] D. M. Janrao, R. P. Shimpi, and R. B. Fadat, "Potentiometric studies of ternary complexes of zinc with vitamins and medicinally important drugs," Journal of Chemical and Pharmaceutical Research, vol. 4, no. 4, pp. 1965-1968, 2012.

[2] G. J. Palm, T. Lederer, P. Orth et al., "Specific binding of divalent metal ions to tetracycline and to the Tet repressor/tetracycline complex," Journal of Biological Inorganic Chemistry, vol. 13, no. 7, pp. 1097-1110, 2008.

[3] G. Karthikeyan, K. Mohanraj, K. P. Elango, and K. Girishkumar, "Synthesis, spectroscopic characterization and antibacterial activity of lanthanide-tetracycline complexes," Transition Metal Chemistry, vol. 29, no. 1, pp. 86-90, 2004.

[4] P. Mishra, "Biocoordination and computational modeling of novel ligands with Bi (V)," International Journal of ChemTech Research, vol. 1, no. 3, pp. 401-419, 2009.

[5] B. S. Sekhon, "Metalloantibiotics and antibiotic mimics-an overview," Journal of Pharmaceutical Education and Research, vol. 1, no. 1, pp. 1-20, 2010.

[6] J. A. Obaleye and A. Lawal, "A synthesis and antibacterial activity of some tetracycline metal complexes," Centrepoint, vol. 14, no. 1-2, pp. 1-6, 2007.
[7] W. R. Chen and C. H. Huang, "Transformation of tetracyclines mediated by $\mathrm{Mn}(\mathrm{II})$ and $\mathrm{Cu}(\mathrm{II})$ ions in the presence of oxygen," Environmental Science \& Technology, vol. 43, pp. 401-407, 2009.

[8] Y. Zhao, J. Geng, X. Wang, X. Gu, and S. Gao, "Tetracycline adsorption on kaolinite: $\mathrm{PH}$, metal cations and humic acid effects," Ecotoxicology, vol. 20, no. 5, pp. 1141-1147, 2011.

[9] S. M. Sultan, I. Z. Alzamil, and N. A. Alarfaj, "Complexometricspectrophotometric assay of tetracyclines in drug formulations," Talanta, vol. 35, no. 5, pp. 375-378, 1988.

[10] S. Schneider, M. O. Schmitt, G. Brehm, M. Reiher, P. Matousek, and M. Towrie, "Fluorescence kinetics of aqueous solutions of tetracycline and its complexes with $\mathrm{Mg}^{2+}$ and $\mathrm{Ca}^{2+}$," Photochemical and Photobiological Sciences, vol. 2, no. 11, pp. 1107-1117, 2003.

[11] C. Jiang and L. Luo, "Spectrofluorimetric determination of human serum albumin using a tetracycline-europium complex," Analytical Letters, vol. 37, no. 6, pp. 1129-1137, 2004.

[12] H. Li, J. Zhang, X. He, and J. Li, "Spectrofluorimetric determination of human serum albumin using a tetracycline-europium complex," Chinese Journal of Chemistry, vol. 22, pp. 177-183, 2004.

[13] S. Liawruangrath, B. Liawruangrath, S. Watanesk, and W. Ruengsitagoon, "Flow injection spectrophotometric determination of tetracycline in a pharmaceutical preparation by complexation with aluminium(III)," Analytical Sciences, vol. 22, no. 1, pp. 15-19, 2006.

[14] A. El Said Mahgoub, E. M. Khairy, and A. Kasem, "Complex formation of uranyl acetate with tetracycline and its utilization for their microdetermination," Journal of Pharmaceutical Sciences, vol. 63, no. 9, pp. 1451-1455, 1974.

[15] P. P. Silva, F. C. S. De Paula, W. Guerra et al., "Platinum(II) compounds of tetracyclines as potential anticancer agents: cytotoxicity, uptake and interactions with DNA," Journal of the Brazilian Chemical Society, vol. 21, no. 7, pp. 1237-1246, 2010.

[16] B. L. Marcial, L. A. S. Costa, W. B. De Almeida, and H. F. Dos Santos, "Structure and properties of the new complexes of platinum (II) with the chemically modified tetracycline CMT3: a theoretical DFT study," Journal of Molecular Structure, vol. 916, no. 1-3, pp. 94-104, 2009.

[17] C. Gu and K. G. Karthikeyan, "Interaction of tetracycline with aluminum and iron hydrous oxides," Environmental Science and Technology, vol. 39, no. 8, pp. 2660-2667, 2005.

[18] R. M. Silverstein and F. X. Webster, Spectrometric Identification of Organic Compounds, John Wiley and Sons, New York, NY, USA, 6th edition, 1997.

[19] E. Solomon and A. Lever, Inorganic Electronic Structure and Spectroscopy, John Wiley and Sons, Toronto, Canada, 1999.

[20] B. Figgis, Introduction to Ligand Fields, Interscience, New York, NY, USA, 1996.

[21] M. Sneed, J. Maynard, and R. Brasted, Comprehensive Inorganic Chemistry, vol. 2, D. Van Nostard Company, 1965.

[22] M. Sneed and R. Brasted, Comprehensive Inorganic Chemistry, vol. 4, D. Van Nostard Company, 1965.

[23] P. Pospisil, P. Ballmer, L. Scapozza, and G. Folkers, "Tautomerism in computer-aided drug design," Journalof Receptors and Signal Transduction, vol. 23, no. 4, pp. 361-371, 2003.

[24] J. Kang, H. Liu, Y.-M. Zheng, J. Qu, and J. P. Chen, "Application of nuclear magnetic resonance spectroscopy, Fourier transform infrared spectroscopy, UV-Visible spectroscopy and kinetic modeling for elucidation of adsorption chemistry in uptake of tetracycline by zeolite beta," Journal of Colloid and Interface Science, vol. 354, no. 1, pp. 261-267, 2011. 
[25] H. A. Duarte, S. Carvalho, E. B. Paniago, and A. M. Simas, "Importance of tautomers in the chemical behavior of tetracyclines," Journal of Pharmaceutical Sciences, vol. 88, no. 1, pp. 111$120,1999$.

[26] D. Harvey, Modern Analytical Chemistry, McGraw-Hill Higher Education a Division of the McGraw-Hill, New York, NY, USA, 2000.

[27] G. H. Morrison, Solvent Extraction in Analytical Chemistry, Butter Worth, 1972.

[28] A.S. H. Al-Kadhumi, Atomic absorption, HPLC and spectrophotometric determination of some antibiotics in pharmaceutical preparations via complexes formation with $\mathrm{Au}(\mathrm{III})$ and $\mathrm{Hg}(\mathrm{II})$ ions [Ph.D. thesis], Department of Chemistry, College of Science, Baghdad University, Baghdad, Iraq, 2011.

[29] D. Skoog, D. West, F. Holler, and S. Cronch, Fundamentals of Analytical Chemistry, International Student Edition (ISE), 8th edition, 2004.

[30] M. S. El-Shahawi, A. S. Bashammakh, and S. O. Bahaffi, "Chemical speciation and recovery of gold(I, III) from wastewater and silver by liquid-liquid extraction with the ion-pair reagent amiloride mono hydrochloride and AAS determination," Talanta, vol. 72, no. 4, pp. 1494-1499, 2007. 

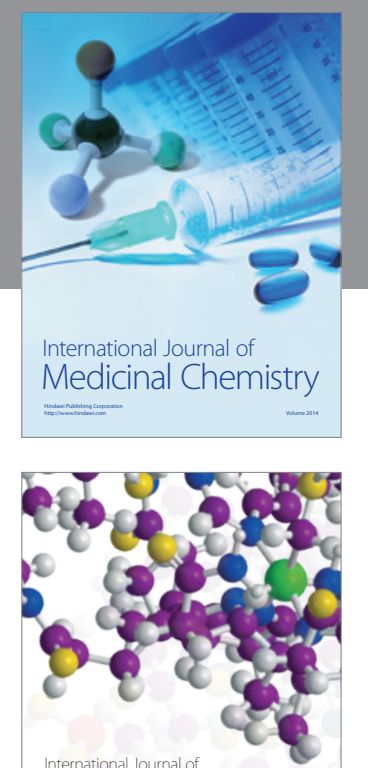

\section{Carbohydrate} Chemistry

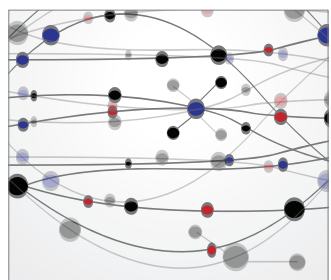

The Scientific World Journal
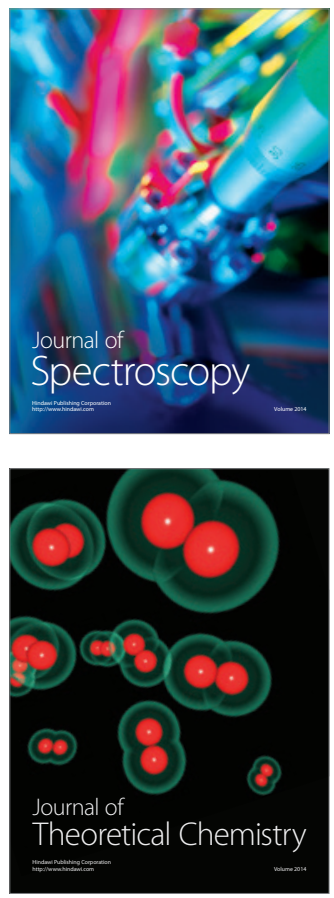
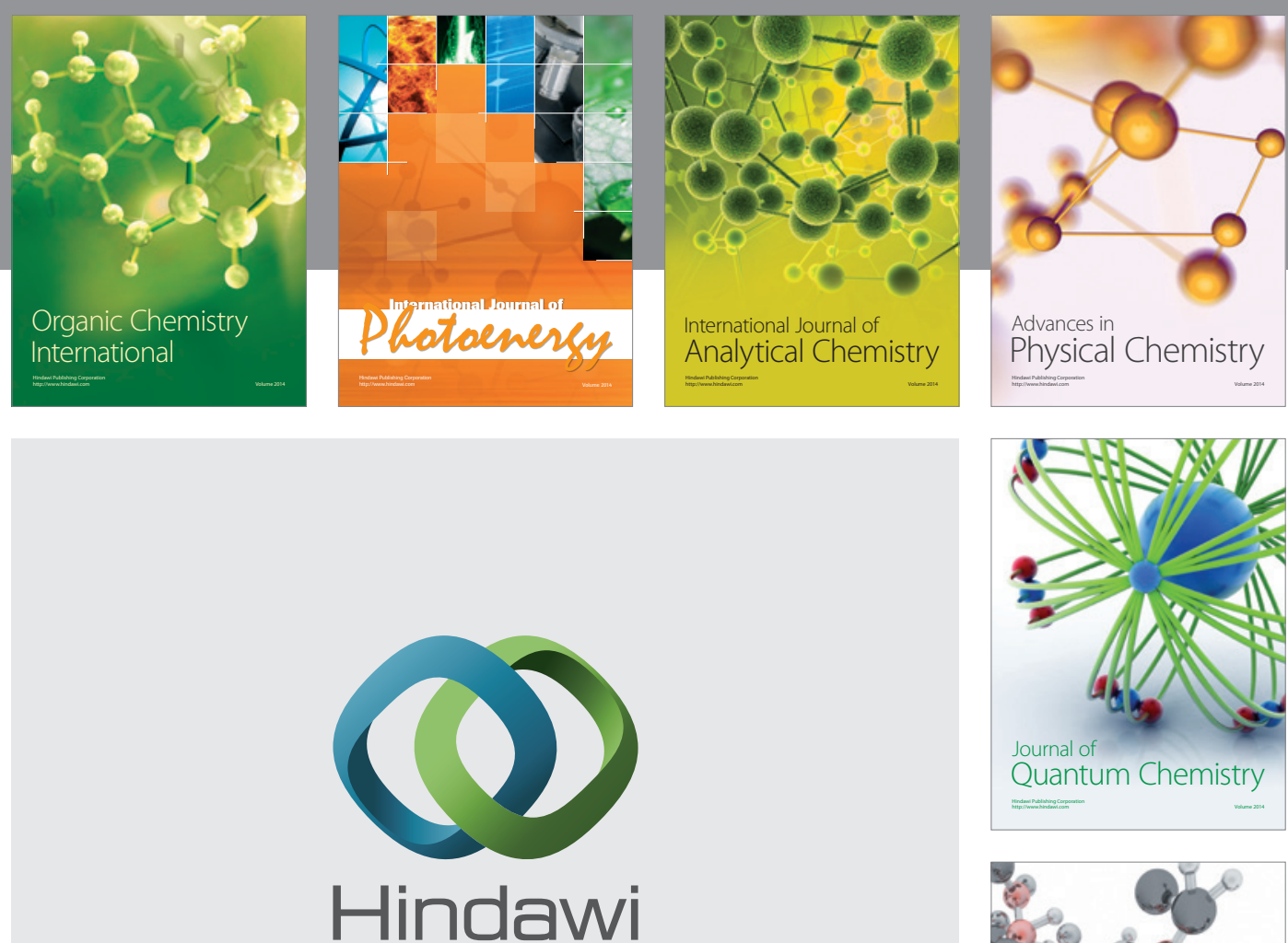

Submit your manuscripts at

http://www.hindawi.com

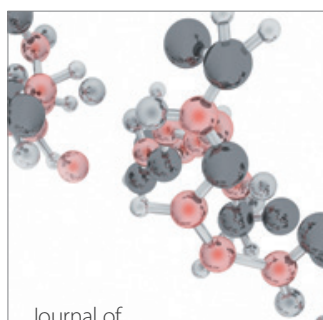

Analytical Methods

in Chemistry

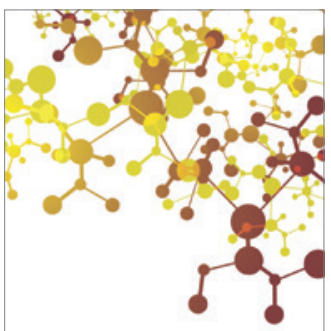

Journal of

Applied Chemistry

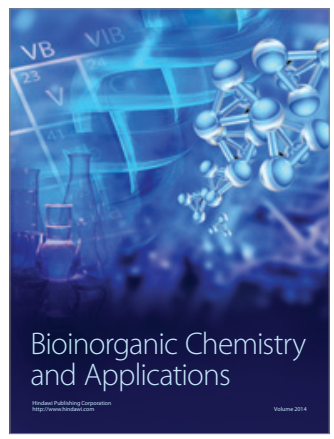

Inorganic Chemistry
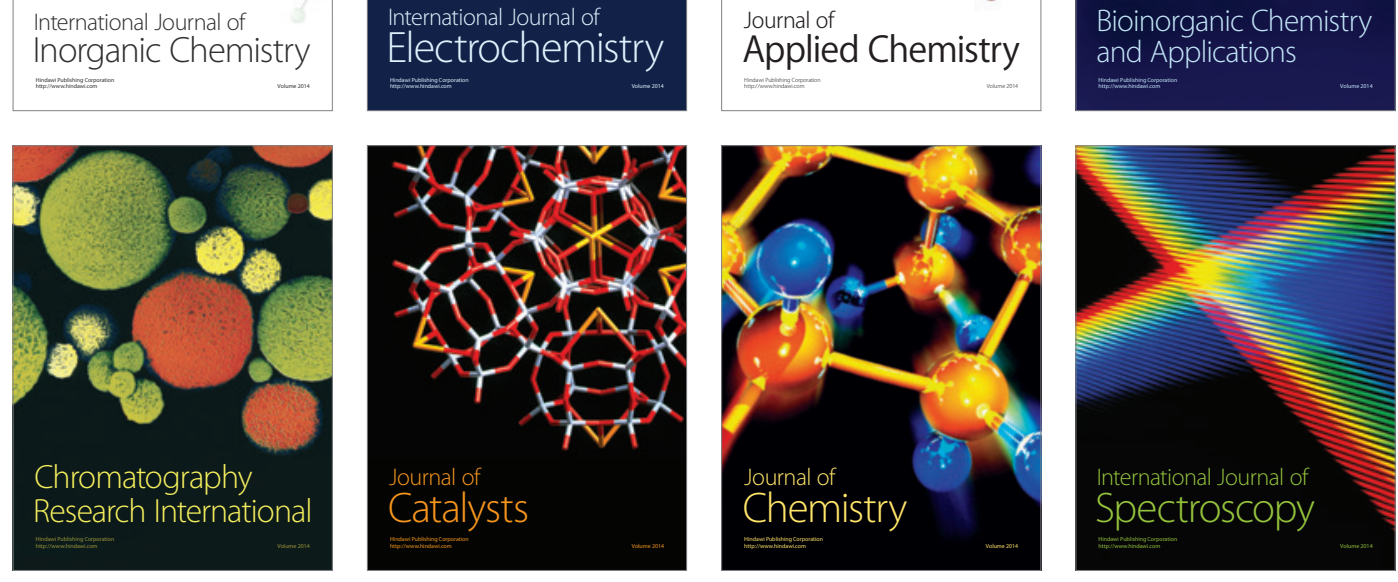